\title{
骨粗鬆症性椎体骨折後偽関節に対する椎体形成術 十後側方固定術の治療成績
}

\author{
井 浦 国 生* 齊 藤太 一* 犀 川 勲* \\ 入江 努* 田中哲 也* 加藤 剛*
}

\section{Clinical Results of Vertebroplasty with Posterolateral \\ Fusion for Nonunion Following Osteoporotic Vertebral Fracture}

\author{
Kunio Iura*, Taichi Saito*, Isao Saikawa*, \\ Tsutomu Irie*, Tetsuya Tanaka*, and Go Katou*
}

\begin{abstract}
骨粗鬆症性椎体骨折後の偽関節に対する椎体形成術十後側方固定術の治療成績を検討した．症例は 10 例（男性 2 例，女性 8 例），手術時年齢は 73.8 歳，罹患椎体高位は T12 が 3 例，T11，L2，L3 がそれぞ れ 2 例， L 1 が 1 例であった．椎体形成術にはハイドロキシアパタイトブロックを使用した. 固定椎間数 は平均 3.5 椎間で，術後経過観察期間は平均 11.7 ヶ月であった。最終経過観察時，麻痺（歩行能力）の 改善は良好であったが，形成椎体高に前後壁ともに平均 $2.5 \mathrm{~mm}$ ，矢状面での後弯 Cobb 角に平均 $5.3^{\circ}$ の 矯正損失を認めた．重篤な全身合併症は認められなかったが，5例に術後新規の椎体骨折を認めた。後弯 矯正の理想角度に関しては明確な指標がないが，本法は本疾患に対して有効な方法であると考えられた。 また，新規椎体骨折の発生も含めて，術後は既存の骨粗鬆症に対する厳重な薬物療法と X 線学的経過観 察が重要である.
\end{abstract}

We evaluated the clinical results of vertebroplasty with posterolateral fusion for nonunion following osteoporotic vertebral fracture. The cases included two males and eight females, with an average age of 73.8 years. The fracture levels were between T11 and L3. We employed hydroxyapatite block for vertebroplasty. The average number of fusion area was 3.5 and followup period was 11.7 months. Physiologically, ambulatory disability improved in most cases after surgery. In radiological assessment, $2.5 \mathrm{~mm}$ collapse of the vertebral height and $5.3^{\circ}$ loss of local kyphosis correction were observed. It is essential to continue medication for basal osteoporosis and radiological follow-up for both loss of correction and occurrence of new vertebral fractures.

Key words : osteoporotic vertebral fracture (骨粗鬆症性椎体骨折), nonunion (偽関節), vertebroplasty (椎体形成術), posterolateral fusion（後側方固定術）

\section{はじめに}

骨粗鬆症患者における椎体骨折のなかに，偽関節か ら圧潰状態となり，遅発性神経麻痺や頑固な遺残性疼 痛を生じる症例が存在することは, 今や普遍的な病態 として認識されるようになった，本稿では，骨粗鬆症 性椎体骨折後の偽関節に対する椎体形成術＋後側方固 定術の治療成績を検討し若干の文献的考察を加えた.

\section{対象および検討項目}

症例は 2006 年 11 月から 2009 年 3 月までに当院に て同手術を施行した 10 例で男性 2 例，女性 8 例であっ た. 手術時年齢は 63〜 84 歳（平均 73.8 歳）であった. 罹患椎体高位は T12 が 3 例，T11，L2，L3 が 2 例， L1 が 1 例であった。手術適応は 9 例が遅発性神経麻 痺, 1 例が根性疼痛であり, 局所の疼痛のみに対して 行ったものはなかった.

\footnotetext{
* 福岡市民病院整形外科 Department of Orthopaedic Surgery, Fukuoka City Hospital, Fukuoka, Japan
} 
手術方法は全例に当該部の後方除圧を施行し, 椎体 形成術にはハイドロキシアパタイトブロックを使用し た. 固定椎間数は $2 \sim 6$ 椎間（平均 3.5 椎間）で pedicle screw system にネスプロンケーブルをを用い た sublaminar taping を併用した。手術時間は208〜 376 分 (平均 270 分), 術後経過観察期間は $3 \sim 28$ ケ 月（平均 11.7 ケ月）であった.

以上の症例に対して, (1)術前後の JOA スコア（自 覚症状), 歩行能力の変化, (2)罹患椎体高並びに後弯 Cobb 角のX線学的推移, (3)術後合併症について検討 を行った.

結果

JOA score（自覚症状：9点満点）では, 術前が $1 \sim 5$ 点で平均 2.5 点, 術後が $3 \sim 7$ 点で平均 5.6 点 であった，平林による改善率は $48 \%$ であった（図 1 ). 歩行能力については, 術前, 車椅子 5 例, 歩行器 3 例, 杖歩行 2 例であったが, 術後は歩行器 3 例, 杖歩行 5 例, 独歩 2 例と改善を認めた（図 2).

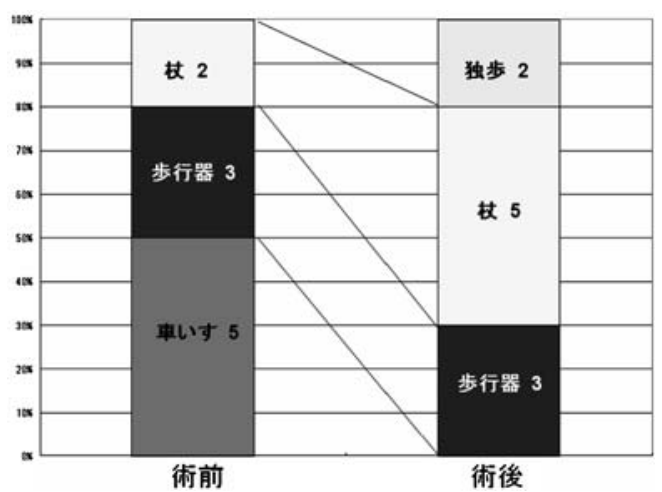

図 2 歩行能力の推移

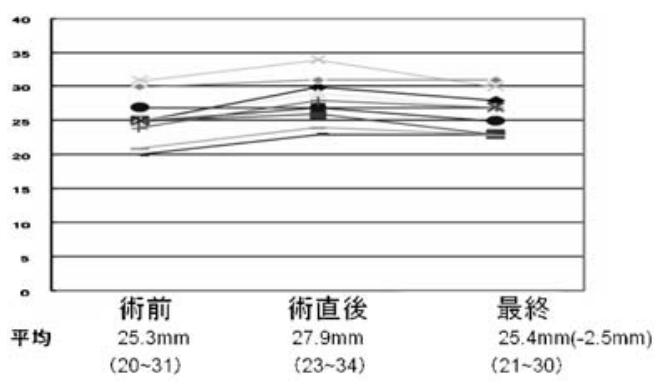

図 4 罹患椎体高の推移（後壁）
罹患椎体高の推移を図 3 , 図 4 に示した。前壁高は 術前 $6 \sim 27 \mathrm{~mm}$ (平均 $15.3 \mathrm{~mm}$ ), 術直後 10 34mm (平均 $23.8 \mathrm{~mm}$ ), 最終観察時 $9 \sim 34 \mathrm{~mm}$ (平均 21.3 $\mathrm{mm}$ ) であり, 最終観察時に $1 \sim 7 \mathrm{~mm}$ (平均 $2.5 \mathrm{~mm}$ ) の矯正損失を認めた（図 3)。後壁高は術前 $20 \sim 31 \mathrm{~mm}$ (平均 $25.3 \mathrm{~mm}$ ), 術直後 $23 \sim 34 \mathrm{~mm}$ (平均 $27.9 \mathrm{~mm}$ ), 最終観察時 21 30mm（平均 25.4mm）であり, 最終 観察時の矯正損失は $2.5 \mathrm{~mm}$ であった（図 4)。後弯 Cobb 角の推移では, 術前がー11 43 (平均 $15.7^{\circ}$ ), 術直後が $-31 \sim 31^{\circ}\left(\right.$ 平均 $\left.5.3^{\circ}\right)$, 最終観察時が -32 $\sim 44^{\circ}$ (平均 $11.3^{\circ}$ ) であり, 最終観察時に平均 $5.3^{\circ}$ の矯正損失が認められた（図 5)。胸腰椎移行部例で

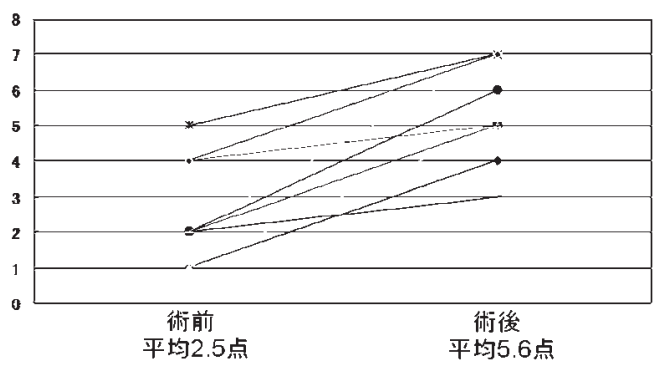

図 1 JOA score（自覚症状 : 9 点満点）の推移

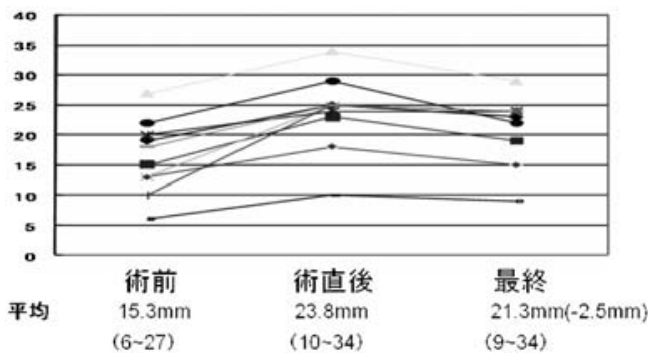

図 3 罹患椎体高の推移（前壁）

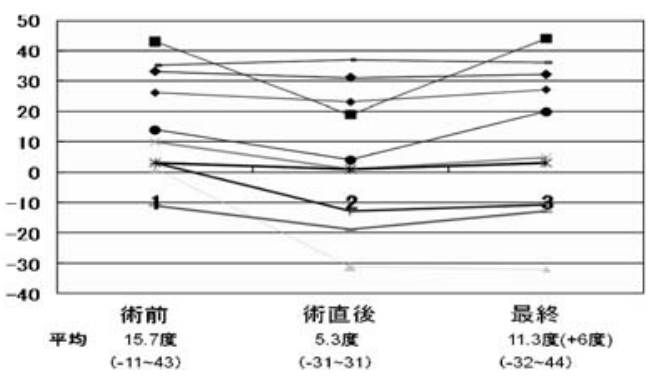

図 5 後弯 $\mathrm{Cobb}$ 角の推移 
後弯変形を大きく矯正した 2 例に矯正損失が大きかつ た.

術後合併症として, 神経・血管損傷, 深部感染を生 じた症例は認められなかつた。新規椎体骨折を 5 例に 認め, pedicle screw 刺入椎体が 1 例, 固定隣接椎体 が 3 例（内 2 例が再度，偽関節，遅発性神経麻痺とな り再手術), 上記以外が 1 例であった。 ハイドロキシ アパタイトブロックの前方逸脱が 2 例に認められたが, いずれも無症状であった。また, pedicle screwの loosening を 2 例に認めた. 肺炎, 肺塞栓症, 術後せ ん妄などの全身合併症はなかった.
症 例 供 覧

\section{症例(1) 70 歳, 女性}

転倒にて T11 椎体骨折受傷. その 1 ケ月後頃より 両足部のしびれが出現し，徐々に下肢脱力のために立 位，歩行が困難となった．脊髄小脳変性症の既往があっ たが，受傷前は手押し車にて歩行していた，受傷から 4 ケ月後に当科紹介受診。術前麻痺は Frankel C で あった. $\mathrm{X}$ 線にて $\mathrm{T} 11$ は楔状, 扁平化し後弯を形成 していた. MRI では T11 後壁が脊柱管内に突出し春 髄を圧迫していた。 T11 椎体形成術+T9-L1 PLF を

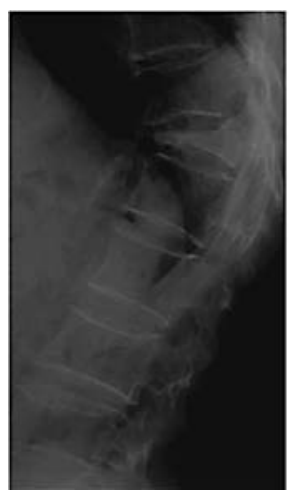

a

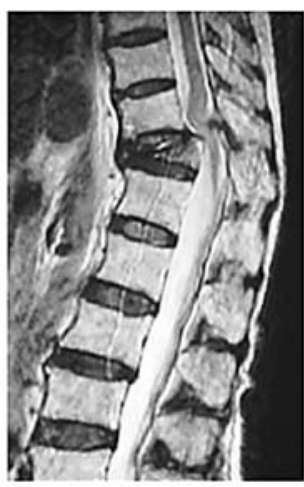

$\mathrm{b}$

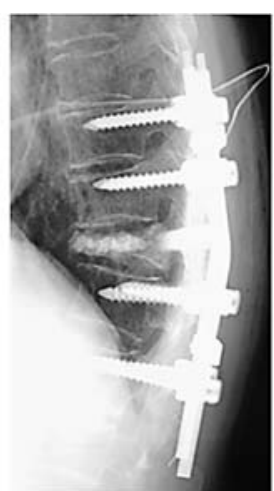

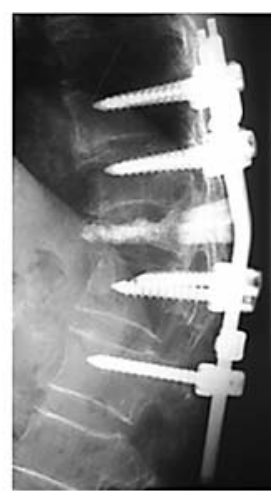

d

図 6 a T11 が圧潰し, 後弯変形を形成

b T11 後壁が春柱管内に突出し，春髄を圧迫している

c T11 椎体形成術 + T9-L1 PLF

$\mathrm{d}$ 術後 5 ケ月 矯正損失はほとんどない

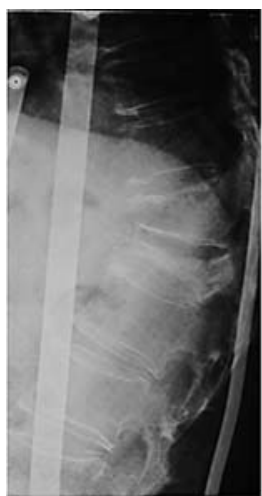

a

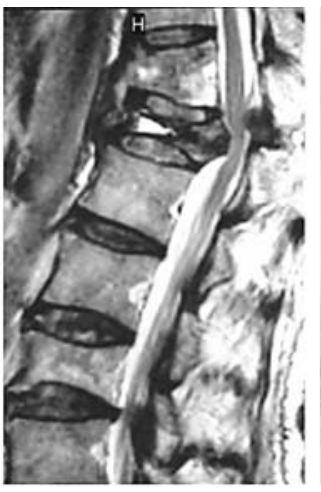

$\mathrm{b}$

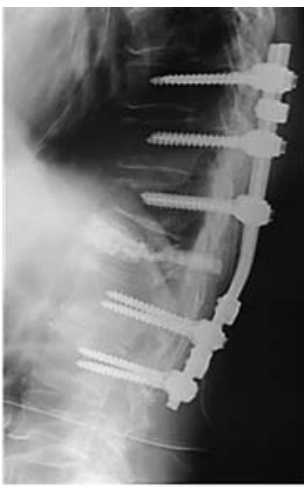

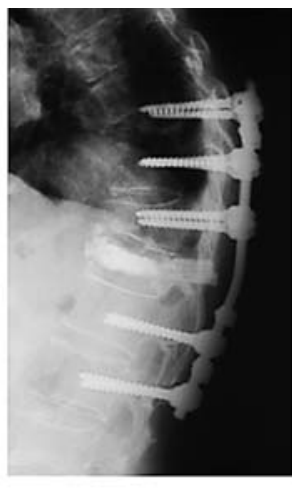

d

図 7 a $\mathrm{T} 12$ 椎体の圧潰と後壁の後方への突出を認める

b T12 後壁による春䯣の圧迫

c T9-L2 PLFを施行

d T9 椎体の圧潰を認め, screw が cut out し, 局所での後弯変形を伴っている 
施行した。術後 5 ヶ月にて矯正損失を認めず（図 6), 麻痺はFrankel D に改善した.

症例(2) 76 歳, 男性

$20 \mathrm{~kg}$ 程度の重量物を運んでいた際に腰痛が出現し, 1 ケ月後より両下肢脱力が出現した. 2 ケ月後に当科 紹介受診となった。 2 年前に脳梗塞の既往があり, 左 下肢麻痺の軽度残存があったが, 独歩安定していた. $\mathrm{X}$ 線にて T12 椎体の圧潰と後壁の脊柱管内への突出 を認め, 後屈にて椎体前方の開大を認めた. MRI で は $\mathrm{T} 12$ 後壁による脊髄の圧迫を認めた。 $\mathrm{T} 12$ 椎体形 成術 +T9-L2 PLF を施行した。術後, 徐々に T9 椎 体の圧潰を認め, screw が cut out し, 局所での後弯 変形を生じたが（図 7), 麻㽻はFrankel D で杖歩行 可能であった.

考察

骨粗鬆症性椎体骨折後の偽関節に対する観血的治療 は大きく, (1)前方手術, (2)後方手術, (3)前方十後方手 術, に分けられる. 後方手術には椎体形成術単独, 椎 体形成術 +固定術, 脊椎短縮術 +固定術などが含まれ る. 手術の目的はいずれも麻痺や疼痛の改善と脊柱支 持性の再建 (再獲得) である. 前方手術は本疾患の神 経圧迫要因である前方要素を直視下に除圧できるとと もに，前方支柱の破綻も同時に再建できるため理にか なった方法ではある.しかしながら，後方手術に比較 して心肺機能を中心とした術後全身合併症に遭遇する 機会も多ぐ)，最近ではあまり頻用されなくなった印 象がある.

これに対して後方手術の利点は，まず普段から慣れ 親しんだ通常の後方アプローチによって行うことがで きるという点である. また, 春柱支持性の再建に関し ても椎体形成術の手技が確立されたことによって, 後 方から実施することが可能となった，椎体形成に用い る材料としては, リン酸カルシウムペーストや骨セメ ントなどがあるが, 我々は操作性, 合併症などの点か らハイドロキシアパタイトブロックを使用している. 椎体形成術に隣接椎間の固定術を併用するか否かに関 しては議論のあるところである. 当科では, 初期固定 性に対する不安から，原則として pedicle screw system とネスプロンケーブルロよる sublaminar taping を用いた後側方固定術を併用している. 骨の脆弱 性を考慮すれば，固定範囲内におけるアンカーは多け
れば多いほど安心である。これにより手術の侵襲が大 きくなることは否定できないが, 山崎らは, 後弯角の 矯正損失が椎体形成術単独では $13.6^{\circ}$, 椎体形成術 + 後方固定術では $3.8^{\circ}$ であったと報告している5).この ほかにも椎体形成術単独例, 後側方固定術併用例にお ける各々の変形矯正損失率に関する報告から ${ }^{12244)}$, 固 定術を併用することの有用性が示唆される.

今回の我々の検討では, 形成椎体高において前後壁 ともに平均 $2.5 \mathrm{~mm}$, 矢状面での後弯 Cobb 角におい て平均 $5.3^{\circ}$ の矯正損失を認めた。 中でも胸腰椎移行 部例で後弯変形を大きく矯正した症例に矯正損失が大 きい傾向があった，齊藤らは，本症に対する前方手術 症例を検討し, 固定範囲内の矯正損失や隣接椎体の骨 折によって術後の矢状面アライメントは結局は術前の レベルにまで戻ったと報告している3.，今回の椎体形 成術，後側方固定術においても，術後，5例（50\%） に新規の椎体骨折を認めた．高齢者で基盤に骨の脆弱 性があり，なおかつ慢性期に至った後弯変形を無理に 矯正しようとしても破綻が生じる可能性が示唆された. 今回の症例では麻痺（歩行能力）の改善はいずれも良 好であり, 重篤な全身合併症も認められなかった，後 弯矯正の理想角度に関しては明確な指標がないものの, 本法は本疾患に対して有効な方法であると考えられた. また, 新規椎体骨折の発生も含めて, 術後は既存の骨 粗鬆症に対する厳重な薬物療法と X 線学的経過観察 が重要である.

$$
\text { ま と め }
$$

(1)骨粗鬆症性椎体骨折後の偽関節に対して椎体形成 術十後側方固定術を行い, 良好な麻痺の改善を得た.

(2)後弯矯正の理想角度に関しては明確な指標がない ものの, 本法は本疾患に対して有効な方法であると考 えられた.

\section{参 考 文 献}

1）星野雅洋，大森圭太：骨粗鬆症性椎体骨折後遅発性障 害対する手術的治療. 別冊整形外科, $52: 110-116,2007$.

2）星野雅洋：骨粗鬆症性椎体骨折败対する HA block を 使用した kyphoplasty。春椎脊䯣, 22 (3)：274-282, 2009.

3) 齊藤太一：骨粗鬆症性椎体圧潰後荤発性神経麻瘦に対 する前方除圧固定術. 西日春椎研会誌, $28 ： 33-36,2002$.

4) 浦山茂樹：胸腰椎移行部の骨粗鬆症性春椎破裂骨折に 
対する局所麻酔下経皮的ハイドロキシアパタイト充填療 法. 別冊整形外科, $52: 103-109,2007$.

5）山崎昭義：骨粗鬆症性椎体骨折後遷延治癒に対する手
術治療. 日本脊椎インストゥルメンテーション学会, 7 (1) : 66-70, 2008. 